\title{
Roles of MicroRNA in T-Cell Leukemia
}

\author{
Mariko Tomita \\ Department Pathology and Oncology \\ Graduate School of Medical Science \\ University of the Ryukyus \\ Japan
}

\section{Introduction}

Previously, cancer researchers have been focused on the genes that code proteins. They have considered those effects on tumorigenesis. However, discoveries of microRNAs (miRNAs) have shed a light on the role of non-protein-coding RNAs in tumorigenesis. The first small non-coding RNA, named lin-4 in Caenorhabditis elegans (C. elegans) was described by Lee et al in 1993 (Lee et al., 1993). Lin-4 codes miRNA that regulates the timing of C. elegans larval development by translational repression (Ambros, 2000). Since then, many miRNAs in different organisms such as plants, C. elegans, Drosophila, and mammals including humans have been discovered substantially. Up to now, the human genome is predicted to encode as many as 1,000 miRNAs.

miRNAs belong to a class of regulatory genes that are single-stranded 19-25 nucleotides non-cording RNAs and are generated from endogenous hairpin-shaped transcripts (Kim, 2005). miRNA genes are located either within the introns or exons of protein-coding genes $(70 \%)$ or in intergenic regions $(30 \%)$. More than $50 \%$ of mammalian miRNAs are located within the intronic regions of protein-coding genes. Most of the intronic or exonic miRNAs are transcribed in parallel with their host genes, indicating that these miRNAs use their host genes transcriptional machinalies. On the other hand, miRNAs produced from intergenic regions are transcribed separately from internal promoters (Rodriguez et al., 2004).

The first step of miRNA synthesis is the transcription of primary miRNA (pri-miRNA) from miRNA genes (Fig.1). pri-miRNAs are transcribed in a RNA polymerase II (Pol II) dependent manner as several hundreds or thousands of nucleotides long polyadenylated RNAs. In the nucleus, the pri-miRNA is processed to a precursor miRNA (pre-miRNA) of 60-100 nucleotides in length with a stem-loop structure by the nuclear protein Drosha that belongs to class II RNase III. Drosha interacts with its cofactor DGCR8 (the DiGeorge syndrome critical region gene 8 protein). Then, the pre-miRNA is exported from the nucleus to the cytoplasm by the Exportin 5/Ran-GTP complex. In the cytoplasm, the pre-miRNA is cleaved by class III RNase III, Dicer, which is a $200-\mathrm{kDa}$ protein and miRNA is produced. Primary function of miRNAs in the cytoplasm is the negative regulation of gene expression by binding to complementary target sequences in the $3^{\prime}$ untranslated region (UTR) of mRNA. Binding of a miRNA to the target mRNA typically leads to translational repression or degradation of mRNA, which means that miRNAs repress the expression of the target genes. In mammals, miRNAs guide the RNA induced silencing complex (RISC) to 


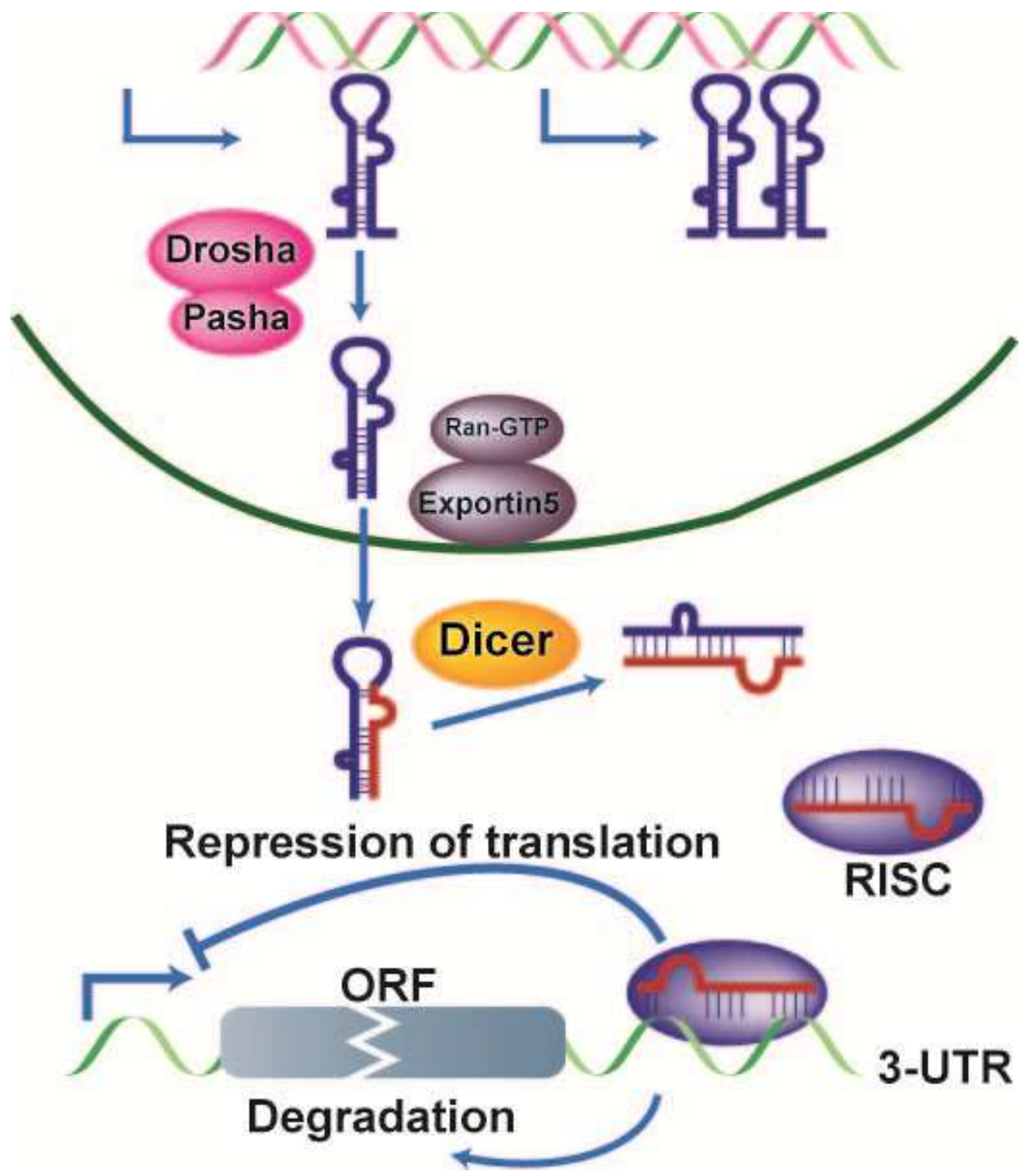

Fig. 1. miRNA biogenesis

complementary target sites of their specific target mRNAs, where endonucleolytically active Ago protein cleaves the mRNAs (Martinez et al., 2002). In contrast, other miRNAs predominantly bind to partially complementary target sites. Such imperfect binding between miRNAs and target mRNAs leads to repression of translation and/or deadenylation, followed by destabilization of the target mRNAs (Pillai et al., 2007). miRNAs are estimated to regulate more than $30 \%$ of mRNAs. Therefore, miRNAs have many roles in biological processes, such as development, differentiation, cell proliferation, apoptosis, and 
stress responses (Bartel, 2004). Moreover, one target gene usually contains binding sites for multiple miRNAs, allowing miRNAs to form more complex regulatory networks of gene expression (Lewis et al., 2003).

\section{2. microRNA in cancer}

Over the recent years, many miRNAs have been implicated in many human cancers. The first evidence for the importance of miRNAs in human cancer was the discovery of the loss of miR-15a/miR-16-1 cluster in chronic lymphocytic leukemia (CLL) (Calin et al., 2002). Since then, aberrant numerous miRNAs expression has been shown to be involved in the development of human cancers.

Many miRNAs have been shown to function as oncogenes in human cancers. Among them, miR-155, which is encoded by nucleotides $241-262$ of B-cell integration cluster (BIC), is the first miRNAs linked with cancer (Metzler et al., 2004). After the discovery, many research groups have shown that miR-155 is highly expressed in various human cancers, including childrend's Burkitt's lymphoma (Metzler et al., 2004), Hodgkin's lymphoma, CLL (Kluiver et al., 2005), primary mediastinal non-Hodgkin's lymphoma (Calin et al., 2005), acute myelogenous leukemia (Garzon et al., 2008), lung cancer, breast cancer (Volinia et al., 2006), and pancreatic cancer (Greither et al., 2010). miR-155 transgenic mice develop acute lymphoblastic leukemia (ALL) and high-grade lymphoma (Costinean et al., 2009). These results support the idea that miR-155 plays a role as oncogene in vivo.

On the other hand, many miRNA encoding genes have been shown as tumor suppressor genes. As mentioned above, miR-15a/miR-16-1 cluster was the first to establish the link between miRNAs and cancer. This study showed loss of miR-15a/miR-16-1 cluster, which are located at chromosome 13q14, a region deleted in more than $65 \%$ of B cell CLL (Calin et al., 2002). These miRNAs induce apoptosis through the negative regulation of the antiapoptotic gene Bcl2 (Cimmino et al., 2005). Indeed, down-regulation of miR-15a/miR-16-1 has been associated with the pathogenesis of CLL (Calin et al., 2008). These data support the idea that miR-15a/miR-16-1 plays a role as tumor-suppressor genes.

In this review, we introduce the accumulating evidences for the central roles that miRNAs play in hematological malignancy, in particular focusing on their role in T-cell leukemia and lymphoma.

\section{3. microRNA in T-cell leukemia and lymphoma}

\subsection{Acute lymphoblastic T-cell leukemia/lymphoma (T-ALL)}

Acute lymphoblastic leukemia (ALL) is the most common neoplasm in children, while it is relatively rare in adults. Although ALL originates from either B or T-cell progenitors, most cases are of B-cell ALL (B-ALL) (Pui \& Evans, 2006). The less common type, T-cell ALL (TALL) is induced by the transformation of T-cell progenitors, and is diagnosed in $10-15 \%$ of children and $25 \%$ of adults with ALL (Copelan \& McGuire, 1995). Molecular mechanisms of leukemogenesis of T-ALL have been investigated intensively. Recent studies revealed that $50-70 \%$ of T-ALLs have gain-of-function mutations in Notch1, a gene that is essential for Tcell development (Ferrando, 2009). miRNAs expression profiles in T- and B-ALL are highly associated with the lineage from which the leukemia derived ( $\mathrm{Lu}$ et al., 2005). Some miRNAs can be discriminative of T-ALL versus B-ALL (Fulci et al., 2009). Although 
miRNAs that associated with leukemogenesis of B-ALL have been well documented (Lawrie, 2008), a few studies have been demonstrated association between particular miRNA and pathogenesis of T-ALL.

Recently, Mavrakis et al. have revealed association between miR-19 and leukemogenesis in T-ALL (Mavrakis et al., 2010). miR-19 was identified within the miR-17-92 cluster. The cluster is located at human chromosome 13q31 in a genomic region that is often amplified in many human cancers (Lu et al., 2005; Nagel et al., 2009). This cluster is also implicated in human hematopoietic malignancies (He et al., 2005; Mendell, 2008; Xiao et al., 2008). Xiao et al. have shown that miR-17-92 cluster is highly expressed in hematopoietic tumors and promotes lymphomagenesis in vivo (Xiao et al., 2008). Indeed, retroviral expression of miR17-92 cluster genes accelerates c-Myc-induced B-cell lymphoma (Mu et al., 2009). The miR17-92 cluster encodes 15 miRNAs including miR-19 with overlapping functions in development (Ventura et al., 2008). More recently, Mavrakis et al. demonstrated that miR-19 expresses at levels seen in other human tumors, enhances lymphocyte survival and is sufficient to cooperate with Notch1 in T-ALL in vivo. They found a 5-17 fold increase in miR19 expression in T-ALL, and less for other miRNAs in the miR-17-92 cluster. miR-19 has a distinct ability to enhance lymphocyte survival in vitro. miR-19 target genes were identified by a large-scale short hairpin RNA screening, including multiple negative regulators in PI3K pathway such as PTEN, Bim, AMP-activated kinase (Prkaa1), and PP2A (Mavrakis \& Wendel, 2010). The expression of these genes is regulated by miR-19 in lymphocytes, indicating that miR-19 produces a coordinate clampdown on multiple negative regulators of PI3K-related survival signals (Mavrakis et al., 2010).

Bhatia et al. recently reported downregulation of the expression of miR-196b in the human T-cell leukemia cell line, and T-ALL patients samples (Bhatia et al., 2011). Same group has shown that miR-196b has the capacity to downregulation the overamplified $c$-myc gene, recognized as a common pathogenomic feature leading to many cancers including B-ALL (Bhatia et al., 2010). In addition, they have demonstrated that miR-196b downregulation several $c-m y c$ effector genes like human telomerase reverse transcriptase (hTERT), the catalytic component of telomerase enzyme responsible for unlimited proliferative potential of cancerous cells, Bcl-2, the anti-apoptotic protein involved in inhibition of cellular apoptosis, and apoptosis antagonizing transcription factor (AATF). Indeed, restoration of miR-196b in EB-3 cells derived from a Burkitt lymphoma leads to significant downregulation of $c-m y c$ and its effector genes and qualifies for tumor suppressor function in B-ALL (Bhatia et al., 2010). On the contrary, miR-196b loses its ability to down regulate $c-m y c$ gene in T-ALL as a consequence of mutations in its target binding region in $3^{\prime} \mathrm{UTR}$ of $c$-myc gene (Bhatia et al., 2011). Although miR-196b is implicated to have different functions in T-ALL from in B-ALL, the role of miR-196b on leukemogenesis of T-ALL is still unclear. Another group's recent study has shown that miR-196a and miR-196b as regulators of the oncogenic ETS transcription factor ERG (Coskun et al., 2011). ERG has been known as playing important physiological and oncogenic roles in hematopoiesis (Baldus et al., 2006). It is also a prognostic factor in a subset of adult patients with T-ALL (Baldus et al., 2006; Loughran et al., 2008). They found that miR-196a and miR-196b expression was associated with an immature immunophenotype (CD34 positive) in T-ALL patients (Coskun et al., 2011). These findings indicate miR-196a and miR-196b as ERG regulators and implicate a potential role for these miRNAs in T-ALL. 


\subsection{Adult T-cell leukemia/lymphoma (ATLL)}

ATLL is an aggressive lymphoproliferative disorder that occurs in individuals infected with human T-cell leukemia virus type 1 (HTLV-1) (Matsuoka \& Jeang, 2007). HTLV-1 causes ATLL in 3-5\% of infected individuals after a long latent period of 40-60 years (Tajima, 1990). More than 20 million people are infected with HTLV-1 worldwide. ATLL occurs mainly in regions where HTLV-1 is endemic, mainly southern Japan, West Africa, and the Caribbean basin. ATLL is classified into four clinical subtypes termed acute, lymphoma, smoldering, and chronic. The prognosis of ATLL patients remains poor with a median survival time of 13 months in aggressive cases (Yamada et al., 2001). HTLV-1 encodes a protein Tax in its genome. The malignant growth and survival of HTLV-1-infected T-cells can be attributed to Tax, that is a modulator of many transcription factors and associations with molecules of signal transduction pathways that alter expression of host-cell genes involved in proliferation, apoptosis, and genetic stability (Marriott \& Semmes, 2005; Boxus et al., 2008). Recent studies have shown the interactions between HTLV-1 and the miRNA regulatory network.

miRNA expression profiling studies in HTLV-1-infected T-cell lines and ATLL patients samples have been performed by some groups (Pichler et al., 2008; Yeung et al., 2008; Bellon et al., 2009). Pichler et al. demonstrated that 4 miRNAs (miR-21, miR-24, miR-146a, and miR155) are upregulated and miR-223 is downregulated in HTLV-1-transfected cells by realtime RT-PCR to analyze selected sets of miRNAs that already been implicated in oncogenic transformation (Pichler et al., 2008). Bellon et al. idenentified aberrant expression of hematopoietic-specific miRNAs included miR-150, miR-155, miR-223, miR-142-3p, and miR142-5p (upregulated) and miR-181a, miR-132, miR-125a, and miR-146b (downregulated) in ATLL cells versus control peripheral blood mononuclear cells (PBMC) and CD4+ T-cells, and HTLV-1-infected cells lines in vitro and uncultured ex vivo ATLL cells (Bellon et al., 2009). These results were confirmed by real-time RT-PCR in additional ATLL cases and infected cell lines. They also demonstrated that treatment of HTLV-1-infected cell lines with an NF- $\mathrm{BB}$ inhibitor (pathenolide) or JNK inhibitor (JNK II) resulted in reduced levels of the miR-155 precursor (Bellon et al., 2009).

Moreover, Yeung et al. demonstrated that 6 miRNAs (miR-9, miR-17-3p, miR-20b, miR-93, miR-130b, and miR-18a) are upregulated and 9 mi-RNAs (miR-1, miR-144, miR-126, miR130a, miR-199a*, miR-338, miR-432, miR-335, and miR-337) are downregulated both in HTLV-1-transformed cell lines and primary ATLL cells (Yeung et al., 2008). To distinguish miRNAs that are responding to proliferative stimuli, they also examined PBMC exposed to phorbol-12-myristate 13-acetate (PMA) compared to untreated PBMC. By these comparisons, they identified 3 miRNAs (miR-93, miR-130b, and miR-18a) that were upregulated in ATLL cells, HTLV-1-infected cell lines and PMA-treated cells, an additional miRNA, miR-335, was downregulated in all three cell types. Then they focused on miR-93 and miR-130b, those were confirmed increased expression in the ATLL samples by real-time RT-PCR. These miRNAs served to regulate tumor protein 53-induced nuclear protein 1 (TP53INP1), that is a cellular tumor suppressor protein whose activity governs cellular survival and proliferation (Yeung et al., 2008). Pichler et al. have shown that TP53INP1 is a potential mRNA target of miR-21, miR-24, miR-146a, and miR-155 (Pichler et al., 2008) .TP53INP1 is induced by the p53 response triggered by various stress treatments such as gamma irradiation, UV irradiation, and oxidative stress. Accumulation of TP53INP1 results in a block in the cell cycle at $G_{1}$ (Tomasini et al., 2003) and triggers apoptosis through increased phosphorylation of p53 on Ser46 (Okamura et al., 2001) and upregulation of 
selected p53-responsive genes such as p53AIP1 (Okamura et al., 2001), p21 and Bax (Tomasini et al., 2001). These results suggest that miRNAs enhance cell growth and suppress apoptosis through targeting TP53INP1.

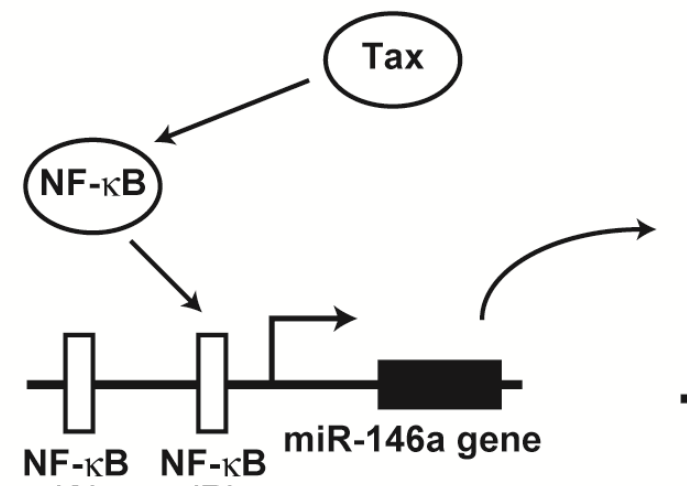

NF- $\mathrm{B} \quad \mathrm{NF}-\kappa \mathrm{B}$ miR-146a gene

(A) (B)

Repression of
translation

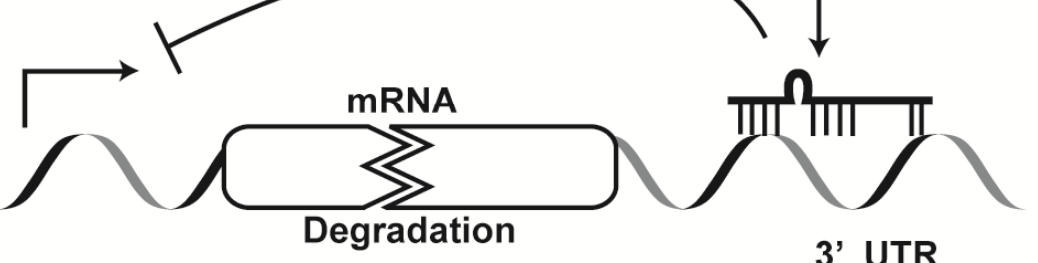

3' UTR
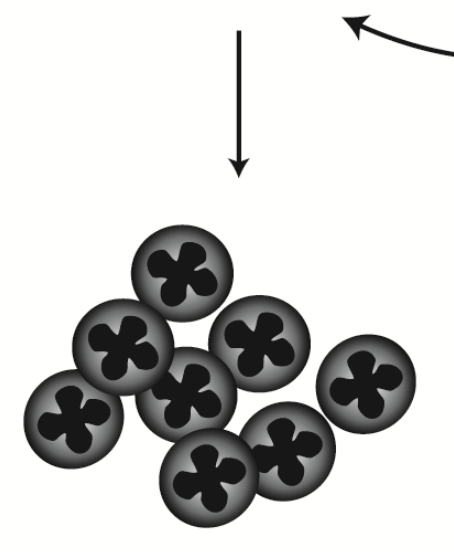

TIII TIII

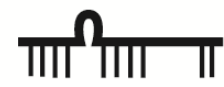

miR-146a

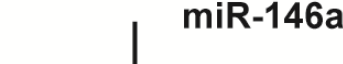

\section{Proliferation of ATL cells}

Fig. 2. Schematic representation of the effects of Tax on miR-146a expression (Tomita et al., 2011) 
Although several miRNA profiling experiments accumulate miRNA subsets up or downregulated in HTLV-1-infected T-cell lines and ATLL patient's samples, data of miRNA expression profiles are not consistent in these reports. This inconsistency could be due to methodological differences in the techniques employed to prepare RNA from the cells and/or to hybridize probes to microarray.

Among the miRNA expression profilings, miR-146a was found to be activated by Tax in an

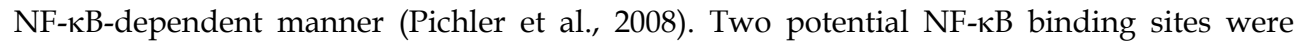
identified in the miR-146a promoter. They found that the proximal NF- $\mathrm{BB}$ binding site on the $m i R-146 a$ gene is responsible for transcriptional activation by Tax (Pichler et al., 2008). Recently, our group demonstrated that miR-146a gene expression is activated by Tax in NF$\kappa B$-dependent manner (Tomita et al., 2011). We found that the miR-146a promoter was highly bound by NF-кB complexes in HTLV-1-infected cells, while treatment with the NF$\kappa B$ inhibitor Bay11-7082 reduced binding and interfered with expression of the miR-146a (Tomita et al., 2011). In contrast to Picheler's results, we observed binding between NF-кB protein and distal NF- $\kappa B$ binding site, not proximal one (Fig. 2). Moreover, we observed that miR-146a plays an important role in the growth of HTLV-1-infected T-cells (Tomita et al., 2011). Treatment of HTLV-1-infected cell lines with an anti-miR-146a inhibitor interfered with their growth and increased the expression levels of TRAF6, a predicted target for miR146a. On the other hand, a growth-enhancing effect was observed in HTLV-1-infected cell line forced to overexpress miR-146a. These results suggest that miR-146a might be a good therapeutic target in ATLL.

Recently, Sasaki et al. demonstrated that ATLL cells showed a decreased level of miR-101 and miR-128a expression compared with the cells from HTLV-1 carriers (Sasaki et al., 2011). Moreover, there was a clear inverse correlation between Enhancer of zeste homolog 2 (EZH2) expression and miR-101 expression or EZH2 expression and miR-128a expression, suggesting that increased EZH2 is caused by the decrease in these miRNAs expression (Sasaki et al., 2011). EZH2 is a critical component of polycomb repressive complex 2 (PRC2), which mediates epigenetic gene silencing through trimethylation of H3K27 (Cao et al., 2002; Czermin et al., 2002). ATLL patients with high EZH2 expression showed shorter survival than patients with low EZH2 expression (Sasaki et al., 2011), indicating that increased EZH2 plays a role in the process of ATLL progression.

\subsection{Sézary syndrome and mycosis fungoides}

Sézary syndrome is a rare aggressive form of primary cutaneous T-cell lymphoma characterized by erythroderma, generalized lymphadenopathy, and the presence of neoplastic cerebriform nucleated $\mathrm{CD}^{+} \mathrm{T}$-cells (Sézary cells) in peripheral blood. Patients with Sézary syndrome have a high leukemic burden and a poor prognostic outcome, with an estimated 5-year survival of only $24 \%$ (Willemze et al., 2005). Mycosis fungoides, the most common cutaneous T-cell lymphoma, is a malignancy of mature, skin-homing T-cells. Sézary syndrome is often considered to represent a leukemic phase of mycosis fungoides. Recently, Ballabio et al. performed miRNA profile of $\mathrm{CD}^{+}{ }^{+} \mathrm{T}$-cells from Sézary syndrome patients. They identified 114 miRNAs specifically expressed in Sézary syndrome (Ballabio et al., 2010). They demonstrated that levels of 4 microRNAs (miR-150, miR-191, miR-15a, and miR-16) correctly predicted diagnosis of Sézary syndrome with $100 \%$ accuracy, whereas miR-223 and miR-17-5p were 96\% accurate. Further analysis revealed that levels of miR-223 distinguished Sézary syndrome samples from healthy controls and patients with mycosis 
fungoides in more than $90 \%$ of samples (Ballabio et al., 2010). miR-342 expression in Sézary syndrome was negatively regulated by miR-199a* expression. Transfection with either miR342 or miR-199a* inhibitor resulted in a significant increase in levels of apoptosis of SeAx cells, suggesting that downregulation of miR-342 plays an important role in the pathogenesis of Sézary syndrome by inhibiting apoptosis (Ballabio et al., 2010). These data indicate that miRNAs are important in the pathogenesis of Sézary syndrome and provide possibilities for the diagnosis and treatment of this disease.

\subsection{Anaplastic large-cell lymphoma}

Anaplastic large cell lymphoma (ALCL) with anaplastic lymphoma kinase (ALK)-positive is a T-cell lymphoma consisting of lymphoid cells that are usually large with abundant cytoplasm and pleomorphic, often horseshoe-shaped nuclei, with ALK gene rearrangements. It tends to occur in children or young adults. The most commonly involved extranodal sites are skin, bone, soft tissues, lung and liver. The 5-year survival of ALCL with ALK-positive patients is about $70 \%$, in contrast to ALCL with ALK-negative, which shows poor prognosis (Swerdlow et al., 2008). Recently, Merkel et al. demonstrated that five members of the miR17-92 cluster were expressed more highly in ALCL with ALK-positive, whereas miR-155 was expressed more than 10-fold higher in ALCL with ALK-negative. Moreover, miR-101 was downregulated in all ALCL model systems, but forced expression of miR-101 attenuated cell proliferation only in ALK-positive and not in ALK-negative cell lines, suggesting different modes of ALK-dependent regulation of its target proteins (Merkel et al., 2010). For future therapeutical and diagnostic application, it will be interesting to study the physiological implications and prognostic value of the identified miRNA profiles.

\section{Conclusion}

Molecular targeting therapy based on miRNAs hold great promise for the development of more effective and less toxic personalized treatment strategies against cancer. Approach of targeting therapy needs deeper knowledge of the molecular changes that associate with development and progression of the diseases. The research on miRNAs is rapidly progressing from in vitro to in vivo and this becomes a powerful tool for molecular targeting therapy for human cancers. Although there is emerging evidence that miRNAs are involved in the pathogenesis of many cancers, including B-cell lymphomas, there are very little published data on the involvement of miRNAs in human T-cell leukemias/lymphomas that were discussed in this review. It is necessary to accumulate more molecular data that indicate association between miRNAs and T-cell leukemia/lymphoma.

\section{Acknowledgment}

I appreciate Dr. Shuji Tomita for valuable discussions and critical reading.

\section{References}

Ambros, V. (2000). Control of developmental timing in Caenorhabditis elegans. Current Opinion in Genetics \& Development 10(4): 428-433.

Baldus, CD., Burmeister, T., Martus, P., Schwartz, S., Gokbuget, N., Bloomfield, CD., Hoelzer, D., Thiel, E. \& Hofmann, WK. (2006). High expression of the ETS 
transcription factor ERG predicts adverse outcome in acute T-lymphoblastic leukemia in adults. Journal of Clinical Oncology 24(29): 4714-4720.

Ballabio, E., Mitchell, T., van Kester, MS., Taylor, S., Dunlop, HM., Chi, J., Tosi, I., Vermeer, MH., Tramonti, D., Saunders, NJ., Boultwood, J., Wainscoat, JS., Pezzella, F., Whittaker, SJ., Tensen, CP., Hatton, CS. \& Lawrie, CH. (2010). MicroRNA expression in Sezary syndrome: identification, function, and diagnostic potential. Blood 116(7): 1105-1113.

Bartel, DP. (2004). MicroRNAs: Genomics, Biogenesis, Mechanism, and Function. Cell 116(2): 281-297.

Bellon, M., Lepelletier, Y., Hermine, O. \& Nicot, C. (2009). Deregulation of microRNA involved in hematopoiesis and the immune response in HTLV-I adult T-cell leukemia. Blood 113(20): 4914-4917.

Bhatia, S., Kaul, D. \& Varma, N. (2010). Potential tumor suppressive function of miR-196b in B-cell lineage acute lymphoblastic leukemia. Molecular and Cellular Biochemistry 340(1-2): 97-106.

Bhatia, S., Kaul, D. \& Varma, N. (2011). Functional genomics of tumor suppressor miR-196b in T-cell acute lymphoblastic leukemia. Molecular and Cellular Biochemistry 346(12): 103-116.

Boxus, M., Twizere, J-C., Legros, S., Dewulf, J-F., Kettmann, R. \& Willems, L. (2008). The HTLV-1 Tax interactome. Retrovirology 5(1): 76.

Calin, GA., Cimmino, A., Fabbri, M., Ferracin, M., Wojcik, SE., Shimizu, M., Taccioli, C., Zanesi, N., Garzon, R., Aqeilan, RI., Alder, H., Volinia, S., Rassenti, L., Liu, X., Liu, CG., Kipps, TJ., Negrini, M. \& Croce, CM. (2008). MiR-15a and miR-16-1 cluster functions in human leukemia. Proceedings of the National Academy of Sciences the United States of America 105(13): 5166-5171.

Calin, GA., Dumitru, CD., Shimizu, M., Bichi, R., Zupo, S., Noch, E., Aldler, H., Rattan, S., Keating, M., Rai, K., Rassenti, L., Kipps, T., Negrini, M., Bullrich, F. \& Croce, CM. (2002). Frequent deletions and down-regulation of micro- RNA genes miR15 and miR16 at 13q14 in chronic lymphocytic leukemia. Proceedings of the National Academy of Sciences the United States of America 99(24): 15524-15529.

Calin, GA., Ferracin, M., Cimmino, A., Di Leva, G., Shimizu, M., Wojcik, SE., Iorio, MV., Visone, R., Sever, NI., Fabbri, M., Iuliano, R., Palumbo, T., Pichiorri, F., Roldo, C., Garzon, R., Sevignani, C., Rassenti, L., Alder, H., Volinia, S., Liu, CG., Kipps, TJ., Negrini, M. \& Croce, CM. (2005). A MicroRNA signature associated with prognosis and progression in chronic lymphocytic leukemia. New England Journal of Medicine 353(17): 1793-1801.

Cao, R., Wang, L., Wang, H., Xia, L., Erdjument-Bromage, H., Tempst, P., Jones, RS. \& Zhang, Y. (2002). Role of histone H3 lysine 27 methylation in Polycomb-group silencing. Science 298(5595): 1039-1043.

Cimmino, A., Calin, GA., Fabbri, M., Iorio, MV., Ferracin, M., Shimizu, M., Wojcik, SE., Aqeilan, RI., Zupo, S., Dono, M., Rassenti, L., Alder, H., Volinia, S., Liu, C., Kipps, TJ., Negrini, M. \& Croce, CM. (2005). miR-15 and miR-16 induce apoptosis by targeting BCL2. Proceedings of the National Academy of Sciences the United States of America 102(39): 13944-13949.

Copelan, EA. \& McGuire, EA. (1995). The biology and treatment of acute lymphoblastic leukemia in adults. Blood 85(5): 1151-1168.

Coskun, E., von der Heide, EK., Schlee, C., Kuhnl, A., Gokbuget, N., Hoelzer, D., Hofmann, WK., Thiel, E. \& Baldus, CD. (2011). The role of microRNA-196a and microRNA- 
$196 \mathrm{~b}$ as ERG regulators in acute myeloid leukemia and acute T-lymphoblastic leukemia. Leukemia Research 35(2): 208-213.

Costinean, S., Sandhu, SK., Pedersen, IM., Tili, E., Trotta, R., Perrotti, D., Ciarlariello, D., Neviani, P., Harb, J., Kauffman, LR., Shidham, A. \& Croce, CM. (2009). Src homology 2 domain-containing inositol-5-phosphatase and CCAAT enhancerbinding protein beta are targeted by miR-155 in B cells of Emicro-MiR-155 transgenic mice. Blood 114(7): 1374-1382.

Czermin, B., Melfi, R., McCabe, D., Seitz, V., Imhof, A. \& Pirrotta, V. (2002). Drosophila enhancer of Zeste/ESC complexes have a histone H3 methyltransferase activity that marks chromosomal Polycomb sites. Cell 111(2): 185-196.

Ferrando, AA (2009). The role of NOTCH1 signaling in T-ALL. Hematology Am Soc Hematol Educ Program, United States.

Fulci, V., Colombo, T., Chiaretti, S., Messina, M., Citarella, F., Tavolaro, S., Guarini, A., Foa, R. \& Macino, G. (2009). Characterization of B- and T-lineage acute lymphoblastic leukemia by integrated analysis of MicroRNA and mRNA expression profiles. Genes Chromosomes Cancer 48(12): 1069-1082.

Garzon, R., Volinia, S., Liu, CG., Fernandez-Cymering, C., Palumbo, T., Pichiorri, F., Fabbri, M., Coombes, K., Alder, H., Nakamura, T., Flomenberg, N., Marcucci, G., Calin, GA., Kornblau, SM., Kantarjian, H., Bloomfield, CD., Andreeff, M. \& Croce, CM. (2008). MicroRNA signatures associated with cytogenetics and prognosis in acute myeloid leukemia. Blood 111(6): 3183-3189.

Greither, T., Grochola, LF., Udelnow, A., Lautenschlager, C., Wurl, P. \& Taubert, H. (2010). Elevated expression of microRNAs 155, 203, 210 and 222 in pancreatic tumors is associated with poorer survival. International Journal of Cancer 126(1): 73-80.

He, L., Thomson, JM., Hemann, MT., Hernando-Monge, E., Mu, D., Goodson, S., Powers, S., Cordon-Cardo, C., Lowe, SW., Hannon, GJ. \& Hammond, SM. (2005). A microRNA polycistron as a potential human oncogene. Nature 435(7043): 828-833.

Kim, VN. (2005). MicroRNA biogenesis: coordinated cropping and dicing. Nature Reviews Molecular Cell Biology 6(5): 376-385.

Kluiver, J., Poppema, S., de Jong, D., Blokzijl, T., Harms, G., Jacobs, S., Kroesen, BJ. \& van den Berg, A. (2005). BIC and miR-155 are highly expressed in Hodgkin, primary mediastinal and diffuse large B cell lymphomas. Journal of Pathology 207(2): 243249.

Lawrie, CH. (2008). MicroRNA expression in lymphoid malignancies: new hope for diagnosis and therapy? Journal of Cellular and Molecular Medicine 12(5A): 14321444.

Lee, RC., Feinbaum, RL. \& Ambros, V. (1993). The C. elegans heterochronic gene lin-4 encodes small RNAs with antisense complementarity to lin-14. Cell 75(5): 843-854.

Lewis, BP., Shih, IH., Jones-Rhoades, MW., Bartel, DP. \& Burge, CB. (2003). Prediction of mammalian microRNA targets. Cell 115(7): 787-798.

Loughran, SJ., Kruse, EA., Hacking, DF., de Graaf, CA., Hyland, CD., Willson, TA., Henley, KJ., Ellis, S., Voss, AK., Metcalf, D., Hilton, DJ., Alexander, WS. \& Kile, BT. (2008). The transcription factor Erg is essential for definitive hematopoiesis and the function of adult hematopoietic stem cells. Nature Immunology 9(7): 810-819.

Lu, J., Getz, G., Miska, EA., Alvarez-Saavedra, E., Lamb, J., Peck, D., Sweet-Cordero, A., Ebert, BL., Mak, RH., Ferrando, AA., Downing, JR., Jacks, T., Horvitz, HR. \& Golub, TR. (2005). MicroRNA expression profiles classify human cancers. Nature 435(7043): 834-838. 
Marriott, SJ. \& Semmes, OJ. (2005). Impact of HTLV-I Tax on cell cycle progression and the cellular DNA damage repair response. Oncogene 24(39): 5986-5995.

Martinez, J., Patkaniowska, A., Urlaub, H., Luhrmann, R. \& Tuschl, T. (2002). Singlestranded antisense siRNAs guide target RNA cleavage in RNAi. Cell 110(5): 563574.

Matsuoka, M. \& Jeang, KT. (2007). Human T-cell leukaemia virus type 1 (HTLV-1) infectivity and cellular transformation. Nature Reviews Cancer 7(4): 270-280.

Mavrakis, KJ. \& Wendel, HG. (2010). TargetScreen: An unbiased approach to identify functionally important microRNA targets. Cell Cycle 9(11).

Mavrakis, KJ., Wolfe, AL., Oricchio, E., Palomero, T., de Keersmaecker, K., McJunkin, K., Zuber, J., James, T., Khan, AA., Leslie, CS., Parker, JS., Paddison, PJ., Tam, W., Ferrando, A. \& Wendel, HG. (2010). Genome-wide RNA-mediated interference screen identifies miR-19 targets in Notch-induced T-cell acute lymphoblastic leukaemia. Nature Cell Biology 12(4): 372-379.

Mendell, JT. (2008). miRiad roles for the miR-17-92 cluster in development and disease. Cell 133(2): 217-222.

Merkel, O., Hamacher, F., Laimer, D., Sifft, E., Trajanoski, Z., Scheideler, M., Egger, G., Hassler, MR., Thallinger, C., Schmatz, A., Turner, SD., Greil, R. \& Kenner, L. (2010). Identification of differential and functionally active miRNAs in both anaplastic lymphoma kinase (ALK)+ and ALK- anaplastic large-cell lymphoma. Proceedings of the National Academy of Sciences the United States of America 107(37): 1622816233.

Metzler, M., Wilda, M., Busch, K., Viehmann, S. \& Borkhardt, A. (2004). High expression of precursor microRNA-155/BIC RNA in children with Burkitt lymphoma. Genes Chromosomes Cancer 39(2): 167-169.

Mu, P., Han, YC., Betel, D., Yao, E., Squatrito, M., Ogrodowski, P., de Stanchina, E., D'Andrea, A., Sander, C. \& Ventura, A. (2009). Genetic dissection of the miR-17 92 cluster of microRNAs in Myc-induced B-cell lymphomas. Genes \& Development 23(24): 2806-2811.

Nagel, S., Venturini, L., Przybylski, GK., Grabarczyk, P., Schmidt, CA., Meyer, C., Drexler, HG., Macleod, RA. \& Scherr, M. (2009). Activation of miR-17-92 by NK-like homeodomain proteins suppresses apoptosis via reduction of E2F1 in T-cell acute lymphoblastic leukemia. Leukemia \& Lymphoma 50(1): 101-108.

Okamura, S., Arakawa, H., Tanaka, T., Nakanishi, H., Ng, CC., Taya, Y., Monden, M. \& Nakamura, Y. (2001). p53DINP1, a p53-inducible gene, regulates p53-dependent apoptosis. Molecular Cell 8(1): 85-94.

Pichler, K., Schneider, G. \& Grassmann, R. (2008). MicroRNA miR-146a and further oncogenesis-related cellular microRNAs are dysregulated in HTLV-1-transformed T lymphocytes. Retrovirology 5: 100.

Pillai, RS., Bhattacharyya, SN. \& Filipowicz, W. (2007). Repression of protein synthesis by miRNAs: how many mechanisms? Trends in Cell Biology 17(3): 118-126.

Pui, CH. \& Evans, WE. (2006). Treatment of acute lymphoblastic leukemia. New England Journal of Medicine 354(2): 166-178.

Rodriguez, A., Griffiths-Jones, S., Ashurst, JL. \& Bradley, A. (2004). Identification of mammalian microRNA host genes and transcription units. Genome Research 14(10A): 1902-1910.

Sasaki, D., Imaizumi, Y., Hasegawa, H., Osaka, A., Tsukasaki, K., Choi, YL., Mano, H., Marquez, VE., Hayashi, T., Yanagihara, K., Moriwaki, Y., Miyazaki, Y., Kamihira, S. \& Yamada, Y. (2011). Overexpression of enhancer of zeste homolog 2 with 
trimethylation of lysine 27 on histone $\mathrm{H} 3$ in adult T-cell leukemia/lymphoma as a target for epigenetic therapy. Haematologica 96(5): 712-719.

Swerdlow, S., Campo, E., Harris, N., Jaffe, E., Pileri, S., Stein, H., Thiele, J. \& Vardiman, J. (2008). WHO Classification of Tumours of Haematopoietic and Lymphoid Tissues, Fourth Edition. Lyon, IARC.

Tajima, K. (1990). The 4th nation-wide study of adult T-cell leukemia/lymphoma (ATL) in Japan: estimates of risk of ATL and its geographical and clinical features. The Tand B-cell Malignancy Study Group. International Journal of Cancer 45(2): 237-243.

Tomasini, R., Samir, AA., Carrier, A., Isnardon, D., Cecchinelli, B., Soddu, S., Malissen, B., Dagorn, JC., Iovanna, JL. \& Dusetti, NJ. (2003). TP53INP1s and homeodomaininteracting protein kinase-2 (HIPK2) are partners in regulating p53 activity. Journal of Biological Chemistry 278(39): 37722-37729.

Tomasini, R., Samir, AA., Vaccaro, MI., Pebusque, MJ., Dagorn, JC., Iovanna, JL. \& Dusetti, NJ. (2001). Molecular and functional characterization of the stress-induced protein (SIP) gene and its two transcripts generated by alternative splicing. SIP induced by stress and promotes cell death. Journal of Biological Chemistry 276(47): 4418544192.

Tomita, M., Tanaka, Y. \& Mori, N. (2011). MicroRNA miR-146a is induced by HTLV-1 tax and increases the growth of HTLV-1-infected T-cells. International Journal of Cancer 129(n/a).

Ventura, A., Young, AG., Winslow, MM., Lintault, L., Meissner, A., Erkeland, SJ., Newman, J., Bronson, RT., Crowley, D., Stone, JR., Jaenisch, R., Sharp, PA. \& Jacks, T. (2008). Targeted deletion reveals essential and overlapping functions of the miR-17 through 92 family of miRNA clusters. Cell 132(5): 875-886.

Volinia, S., Calin, GA., Liu, CG., Ambs, S., Cimmino, A., Petrocca, F., Visone, R., Iorio, M., Roldo, C., Ferracin, M., Prueitt, RL., Yanaihara, N., Lanza, G., Scarpa, A., Vecchione, A., Negrini, M., Harris, CC. \& Croce, CM. (2006). A microRNA expression signature of human solid tumors defines cancer gene targets. Proceedings of the National Academy of Sciences the United States of America 103(7): 2257-2261

Willemze, R., Jaffe, ES., Burg, G., Cerroni, L., Berti, E., Swerdlow, SH., Ralfkiaer, E., Chimenti, S., Diaz-Perez, JL., Duncan, LM., Grange, F., Harris, NL., Kempf, W., Kerl, H., Kurrer, M., Knobler, R., Pimpinelli, N., Sander, C., Santucci, M., Sterry, W., Vermeer, MH., Wechsler, J., Whittaker, S. \& Meijer, CJ. (2005). WHO-EORTC classification for cutaneous lymphomas. Blood 105(10): 3768-3785.Xiao, C., Srinivasan, L., Calado, DP., Patterson, HC., Zhang, B., Wang, J., Henderson, JM., Kutok, JL. \& Rajewsky, K. (2008). Lymphoproliferative disease and autoimmunity in mice with increased miR-17-92 expression in lymphocytes. Nature Immunology 9(4): 405-414.

Yamada, Y., Tomonaga, M., Fukuda, H., Hanada, S., Utsunomiya, A., Tara, M., Sano, M., Ikeda, S., Takatsuki, K., Kozuru, M., Araki, K., Kawano, F., Niimi, M., Tobinai, K., Hotta, T. \& Shimoyama, M. (2001). A new G-CSF-supported combination chemotherapy, LSG15, for adult T-cell leukaemia-lymphoma: Japan Clinical Oncology Group Study 9303. British Journal of Haematology 113(2): 375-382.

Yeung, ML., Yasunaga, J., Bennasser, Y., Dusetti, N., Harris, D., Ahmad, N., Matsuoka, M. \& Jeang, KT. (2008). Roles for microRNAs, miR-93 and miR-130b, and tumor protein 53-induced nuclear protein 1 tumor suppressor in cell growth dysregulation by human T-cell lymphotrophic virus 1. Cancer Research 68(21): 8976-8985. 


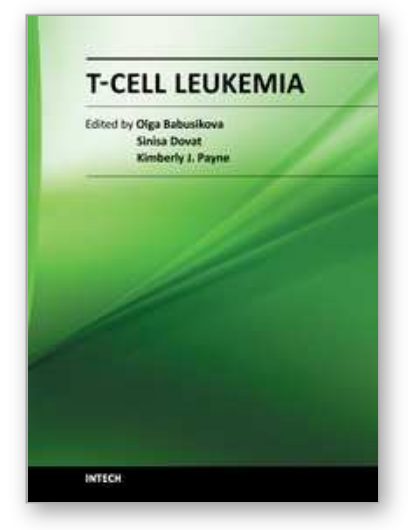

\author{
T-Cell Leukemia \\ Edited by Dr Olga Babusikova
}

ISBN 978-953-307-400-9

Hard cover, 234 pages

Publisher InTech

Published online 26, October, 2011

Published in print edition October, 2011

The purpose of this book is to provide a comprehensive review of the scientific advances in T-cell malignancies and to highlight the most relevant findings that will help the reader understand both basic mechanisms of the disease and future directions that are likely to lead to novel therapies. In order to assure a thorough approach to these problems, contributors include basic scientists, translational researchers and clinicians who are experts in this field. Thus, the target audience for this book includes both basic scientists who will use this book as a review of the advances in our fundamental knowledge of the molecular mechanisms of T-cell malignancies, as well as clinicians who will use this book as a tool to understand rationales for the development of novel treatments for these diseases.

\title{
How to reference
}

In order to correctly reference this scholarly work, feel free to copy and paste the following:

Mariko Tomita (2011). Roles of MicroRNA in T-Cell Leukemia, T-Cell Leukemia, Dr Olga Babusikova (Ed.), ISBN: 978-953-307-400-9, InTech, Available from: http://www.intechopen.com/books/t-cell-leukemia/roles-ofmicrorna-in-t-cell-leukemia

\section{INTECH}

open science | open minds

\section{InTech Europe}

University Campus STeP Ri Slavka Krautzeka 83/A 51000 Rijeka, Croatia Phone: +385 (51) 770447

Fax: +385 (51) 686166 www.intechopen.com

\section{InTech China}

Unit 405, Office Block, Hotel Equatorial Shanghai No.65, Yan An Road (West), Shanghai, 200040, China 中国上海市延安西路65号上海国际贵都大饭店办公楼 405 单元 Phone: +86-21-62489820

Fax: $+86-21-62489821$ 
(C) 2011 The Author(s). Licensee IntechOpen. This is an open access article distributed under the terms of the Creative Commons Attribution 3.0 License, which permits unrestricted use, distribution, and reproduction in any medium, provided the original work is properly cited. 